\title{
鋼索用素線の引張片振り曲げ疲労試験における 亀裂の発生と進展について*
}

\author{
上田 和 彦 ${ }^{1}$ 藤 中 雄 $\Xi^{2}$
}

[UDC $620.178 .3: 622.673]$

\author{
Crack Initiation and Growth in Fatigue Test of Curved Steel Wire \\ under Both Tension and Pulsating Bending \\ by Kazuhiko UEDA ${ }^{1}$ and Yuzo FUJINAKA ${ }^{2}$ \\ 1. Maizuru College of Technology, Maizuru 625 \\ 2. Faculty of Engineering, Kyoto University, Sakyo-ku, Kyoto 606
}

This paper reports on an acoustic emission method and a DC electric potential method, as the measure for evaluating the progression of cracks during the fatigue test, of curved steel wires under both tension and pulsating bending.

The cumulative count of the $\mathrm{AE}$ event and the electric potential ratio (potential/initial potential) those increase with growing of a crack are shown. Considering the relation between electric potential ratio and relative crack depth, the initiation and growing of a crack are also investigated.

The results are as follows.

(1) Crack initiation happens at about $40 \%$ of total lifetime.

(2) Crack grows rapidly in the last several minutes before failure.

(3) Increment $\left(\left(v-v_{0}\right) / v_{0}\right)$ of electric potential ratio $\left(v / v_{0}, v_{0}\right.$ : initial value $)$ is approximately proportional to the three-halves power of the area of the fatigue fractured region in a specimen.

KEY WORDS: Tension and Pulsating Bending, Crack Initiation and Growth, Cumulative Count of AE Event, Electric Potential Ratio, Relative Crack Depth, Area of Fatigue Fractured Region

\section{1. 緒言}

鋼索の疲労を検討するにあたり，それを構成している素線の疲 労特性を知るとともに疲労破壊現象を解明するために, 硬鋼線の 引張曲げ疲労試験を行い, S-N線図の作成によって素線の反りが 試験中の素線応力におよぼす影響と疲労破壞によって生じた破断 面の検討を行ってきた ${ }^{1) 2)}$ 。

本研究はそれに引続いて素線の疲労破壊の進行状況を解明する ために, アコースティック・エミッション法（以下「AE法」と 称する $)^{3)}$ によって破壊の微視的な過程に対応して発生した突発 型の弾性波（超音波）を，1チャンネルの必要最小限度の装置の ためイベント計数法によって電压パルス信号に変えて A E 累積総 数を測定すると同時に, 別に直流電位差法（以下「電位差法」と 称する $)^{4)}$ によって試料に一定電流を通しているとき破壊にとも なって生じたき裂による抵抗の変化を電王の変化として測定する ことにより,き裂の発生時期とき裂の進展状況についての検討を 行った。

\section{2. 実験装置および実験方法}

\section{$2 \cdot 1$ 試料}

\footnotetext{
* 1989 年 11 月 6 日受付 1990 年 4 月 18 日受理 昭和 63 年度資源 ·素材関係学協会合同秋季大会にて一部発表

1. 正会員 舞鶴工業高等専門学校助教授 機械工学科

2. 正会員 工博 京都大学教授 工学部資源工学科 (現 福井工業大学)

キーワード : 引張片振り曲げ, き裂の登生と進展, $\mathrm{A} \mathrm{E}$ 事象総数, 電気 ポテンシャル比(電位差比)，相対き裂深さ，疲労破断部 の面積
}

供試材は直径 $1.17 \mathrm{~mm}$, 炭素量 $0.61 \%$, マンガン量 $0.42 \%$, けい 素量 $0.22 \%$, 表面のマイクロビッカース硬度 418 , 引張強さ 177.7 $\mathrm{kgf} / \mathrm{mm}^{2}$ の鋼索用硬鋼線である。自然状態で曲率半径 1,100 $1,500 \mathrm{~mm}$ の反りがみられる。本研究ではこれを長さ $480 \mathrm{~mm}$ に切断 し有効長さ $200 \mathrm{~mm}$ の試料として用いた。

\section{$2 \cdot 2$ 実験装置}

図 1 は素線の引張曲げ疲労試験機で, 試料の素線に約 $300 \mathrm{cpm}$

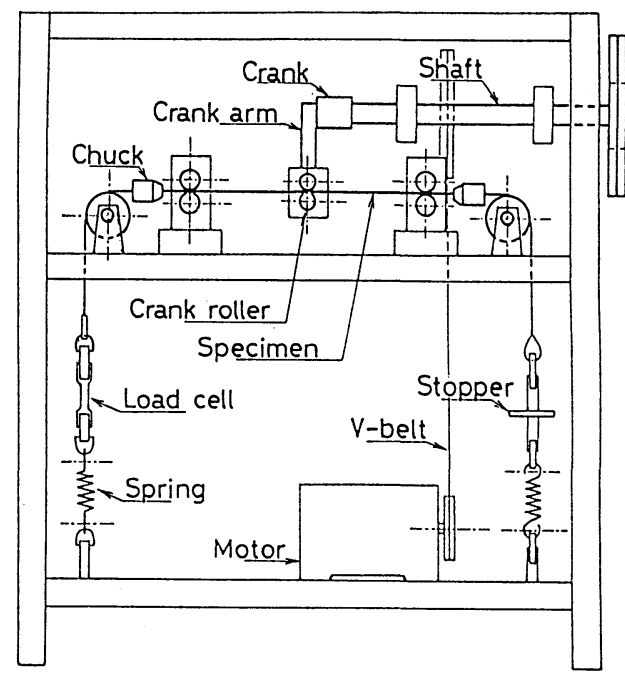

Fig. 1 Fatigue testing equipment for steel wire under both tension and pulsating bending. 


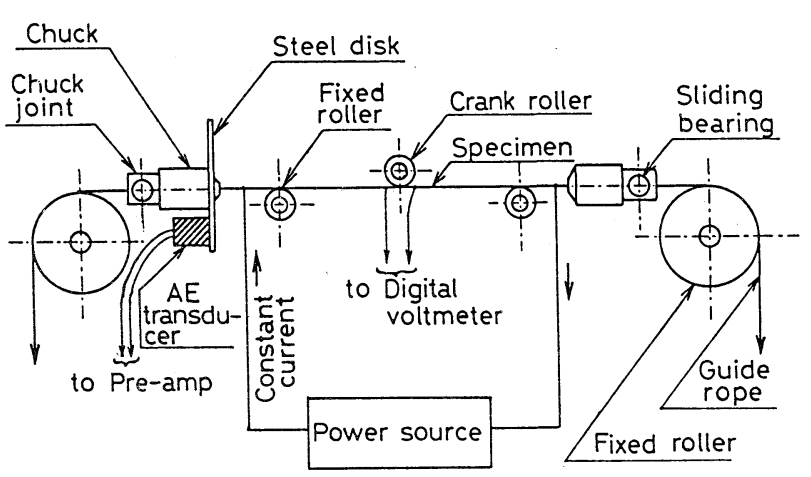

Fig. 2 Chucking of a sample and attaching of an AE transducer.

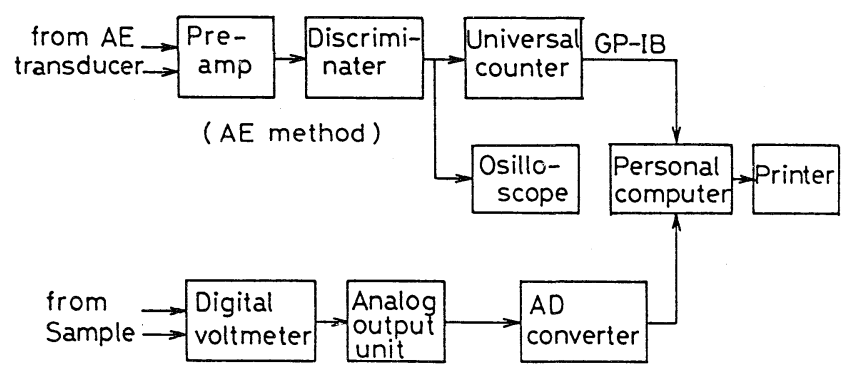

(Electric potential method)

Fig. 3 Schematic diagram of the measurement system.

の片振りの繰返し曲げを与える。素線の引張荷重の測定には 4 ゲ ージ式の軽量ロードセルを使用した ${ }^{1)}$ 。

図 2 と図3はそれぞれ試料取付部と計測装置の概要を示したも ので, 電位差法では試料に通電するため試料と疲労試験機本体と は電気的に絶縁することが必要である。そのため試料支持器とク ランク・ローラにはそれぞれセラミックボール軸受と表面にセラ ミックのコーティングが施された軸受を使用し, チャック継手と 引張用ロープ先端部の嵌合い部分にはフッ素樹脂系の滑り軸受を 使用した。電位差の測定には分解能が $1 \mu \mathrm{V}$ のデジタルマルチメ ータを使用する。

$\mathrm{A} \mathrm{E}$ 法では直径 $70 \mathrm{~mm}$, 厚さ $2 \mathrm{~mm}$ の鋼製の円板をチャック前面 にビス止めして, それにグリースを塗って取付金具でA E センサ を圧着する。A E センサは差動型を使用し, 前置増幅器の増幅度 は $40 \mathrm{~dB}$ で, 振幅弁別器は原波形をパルスに変換するのに高レべ

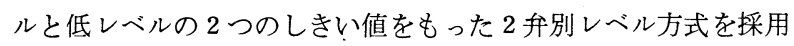
した。A E 波形の観察用にはオシロスコープを用いる。

図 4 は探触子の平行移動装置で, ばねを使って 2 本の探触子を 一定の圧力で人工切欠き部分を間にはさんで試料に押しつけなが ら, 試料に平行に移動して 2 探触子間の電位差を測定する機構と なっている。

\section{$2 \cdot 3$ 実験方法}

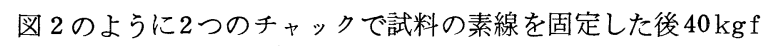
と $60 \mathrm{kgf}$ および $80 \mathrm{kgf}$ の引張荷重を与える。疲労試験機を運転す ると所定のたわみ量 $(1+8.5 \mathrm{~mm})$ がクランクの押し下げによって 与えられる。試料とクランク・ローラが常に離れないようにする ために, クランクが最も高い位置にあるときでも $1 \mathrm{~mm}$ の押し下げ 量を与えるようにしてある。本研究では引張・片振り曲げ・疲労 試験機として使用する。

電位差法では, クランク・ローラをはさんでおよそ $17 \mathrm{~mm}$ の間 隔で試料の下面にスポット溶接した細いリード線を電位差計に導 くようにしたあと, 実験中の試料には定電流電源からの直流 0.6 $\mathrm{A}$ を通電して, 2 本のリード線間の電位差を一定時間（例えば,

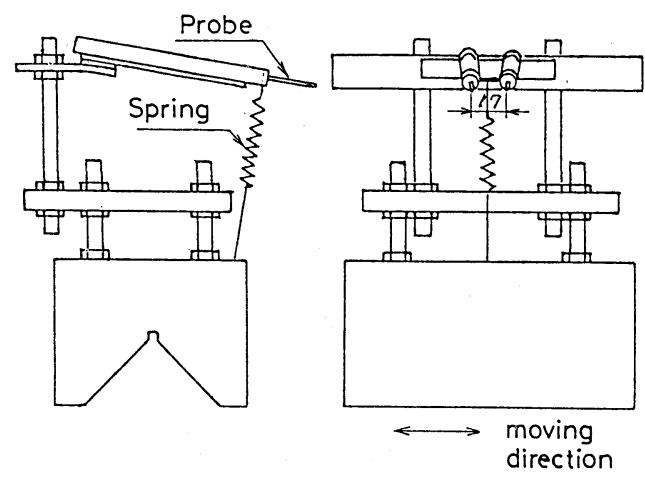

Fig. 4 Device for moving probe parallel to a sample.

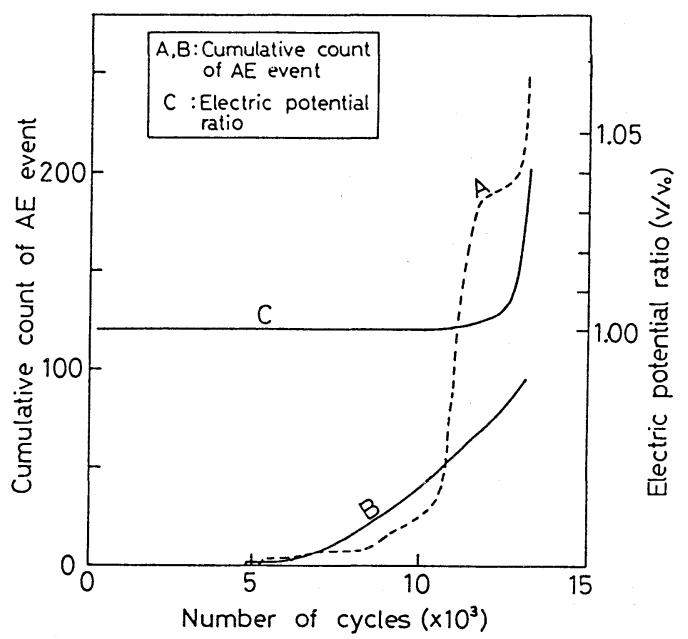

Fig. 5 Changing with time of both cumulative count of AE event and electric potential ratio $\left(v / v_{0}\right.$, i.e. potential/ initial potential).

始めは 1 分おきすなわち約 300 回ごとで, 破断が近づくと 10 秒お きすなわち約 50 回ごと) おきに測定する。ここで電流值 $0.6 \mathrm{~A}$ は, 長時間連続的に試料に通電したときほとんど温度上昇を生じない ほぼ最大の值である。試料にあらかじめ種々の切欠きをつけたも のを隼備して, 疲労試験時と同じ電流を流して探触子の平行移動 装置を使って, 切欠きの深さと電位差の変化すなわち電気抵抗の 変化との関係を求めるようにした。

$\mathrm{AE}$ 法では振幅弁別器の増幅度を $40 \mathrm{~dB}$ に設定し, 電気的およ び機械的雑音を低減するためにローパスフィルタを $1 \mathrm{MHz}$ ，ハイ パスフィルタを $100 \mathrm{KHz}$ に設定した。

\section{3. 実験結果および考察}

図 5 は繰返し曲げ回数の増加に伴う電位差比と A E 累積数の変 化状況を示すもので, 試験後期の破壊の直前の変化をよくとらえ ることができている。ここで電位差比は「2本のリード線間の電 位差 $V$ のその初期値 $V_{0}$ に対する比率」である。

$\mathrm{AE}$ 信号は比較的小さく電気的機械的雑音の影響を受けやすく 実験のたびにかなり大きく值が变りがちであるが, 本実験では多 くの場合, 図 5 の A E 累積曲線 $\mathrm{A}$ に示されているようにき裂の進 展が早くなって電位差が増加し始めた時期にあわせて A E 累積総 数の勾配すなわち A E 発生率が急激に大きくなっている。ときに は同図中の A E 累積曲線 B が示すように急な立上りの見られない 場合もあった。一般に A E には連続型と突発型の 2 種類があって, 突発型は破壞の微視的な過程すなわち微小な割れの進行に対応し てひずみェネルギーが解放されるとき生ずるため, 塑性変形とと 
もに生ずる連続型に比べてェネルギーレベル（従って信号レベル） が高い。先に述べたように本実験では信号レベルが大きく断続的 に発生する突発型の A E を扱う関係上, A E 信号の発生頻度とい う物理的意味から妥当なカウント方式であることおよび 1 チャン ネルの必要最小限度の装置を使用しているためイベント計数法を 採用し，不感時間を零としている。リングダウン計数法は一定の しきい值を越えた弾性波のサイクル数を全部数える振幅による一 種の重みづけ計数法であるが, ここではイベント計数法なのでA $\mathrm{E}$ の数と信号レベルとは直接の関係はなく, 破断の直前でA Eの 発生が多くなり A Eの数が増加するものと考えられる。波形観察 によって本実験の場合はすべて突発型であることが認められ，A $\mathrm{E}$ 累積曲線の両者の場合とも全寿命の $40 \%$ の頃から A Eが出現し， ここがほぼき裂の発生時期と考えられる。

本実験では, き裂深さが直径の $10 \%$ 近くに達してから電位差法 によるき裂の検出が可能で, 検出時期は繰返し数で測って破断の $2,000 \sim 3,000$ 回まえである。これは時間にして 7 10 分前に相当 している。電位差比曲線は図 5 に示されているような形となって いて, 破断直前では繰返し数に対して指数関数的に急激に増加し ている。全寿命の残り $1 / 6 \sim 1 / 10$ の時期からき裂が急速に進展し たことが分かり，本実験の疲労破壊の特性を典型的に表しているま のと認められる。破壊の直前までの測定值が十分安定で雑音性障 害も少ないので, この方法はき裂の計測のためにすぐれた方法で あると認められる。

オシロスコープによる観察結果では $\mathrm{A} \mathrm{E}$ 波形の振幅は, 始めは 雑音レベルよりもわずかに大きい程度であるが，しだいに大きく なり破断直前には少なくとも数倍から10倍程度にはなっているこ とが認められた。

き裂深さと電位差の関係を知る較正は, 試料に種々の深さの人 工切欠きをつけ，探触子の平行移動装置を用いて行うことは前に 述べたが, 切欠き深さと電位差の増加分すなわち抵抗の増加分と の関係として示すと図6のようになる。同図から切欠き深さと抵 抗の堌加率との関係が分かり, 相対切欠き深さがおよそ0.28を境 にして増加率が 2 倍ほど大きくなっている。切欠き深さとその部 分の断面積の減少量とは一定の関係があるので, 図 6 を抵抗の増 加分すなわち電位差比の増加分 ( $X$ とする) と断面積の減少量 (その相対值を $Y$ とする) の関係に置き換え， $X$ と $Y$ の関係を両 対数グラフに表して最小 2 乗法によって直線の近似式を求めた後, 通常のグラフの関係に戻すと $X=0.092 Y^{1.29}$ 関係式が得られる。

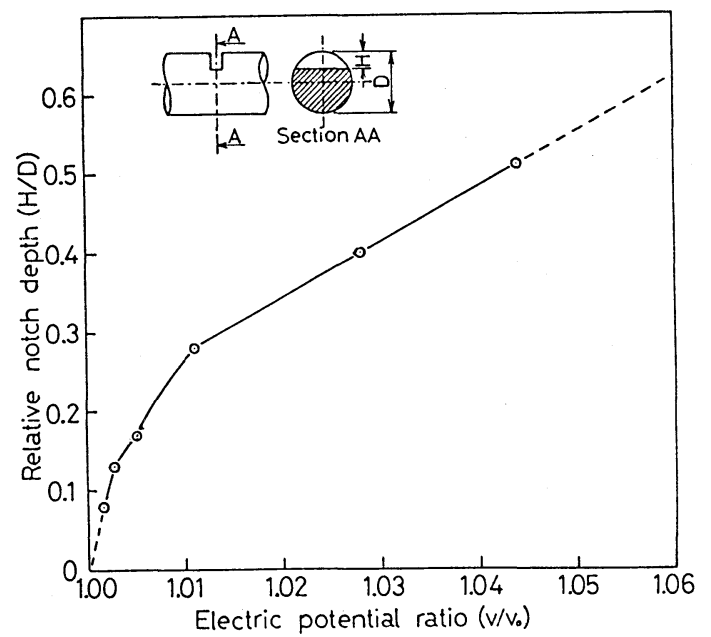

Fig. 6 Relation between electric potential ratio $\left(v / v_{0}\right.$, i.e potential/initial potential) and relative notch depth $(H / D$, i.e. depth/diameter $)$.

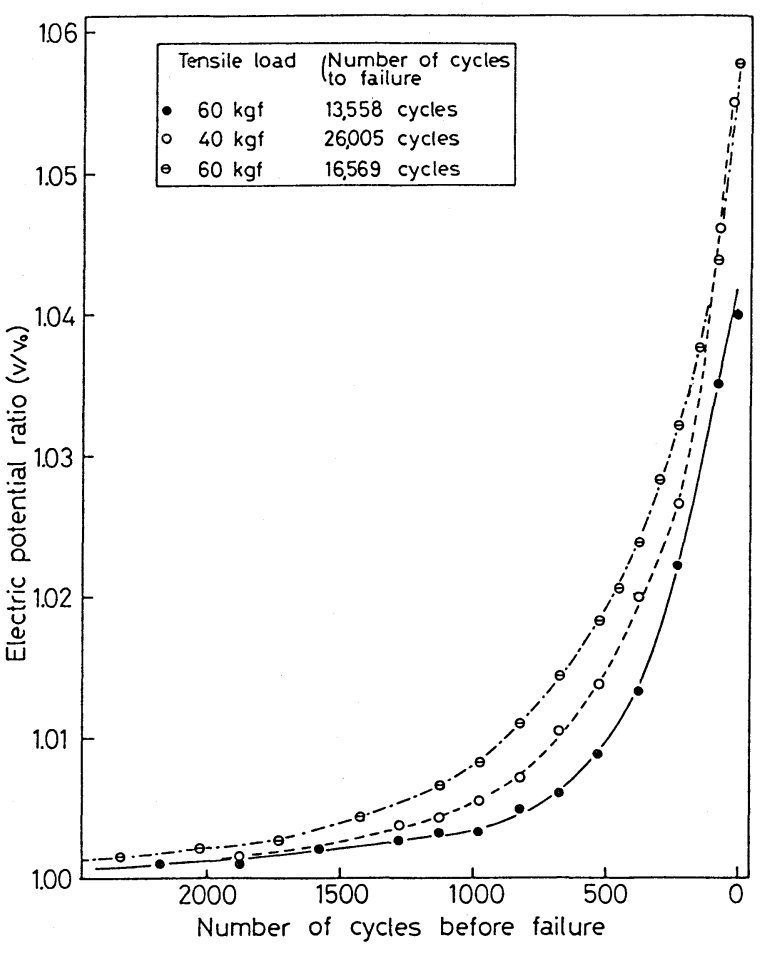

Fig. 7 Changing with time of electric potential ratio $\left(v / v_{0}\right.$, i.e. potential/initial potential) before failure.

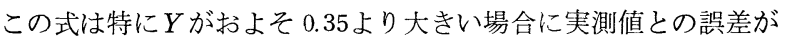
大きくなるので，実測值のバラッキが相対的に小さく信頼度が高 いYがおよそ 0.3 より大きい範用で，誤差が小さくなるように修 正すると $X \cong 0.12 Y^{1.5}$ の関係式が得られる。言い換えると切欠き による抵抗の増加分すなわち電位差の增加分は, 切欠部の断面積 の減少量すなわち疲労破断部の面積の $3 / 2$ 乗にほぼ比例して増加 している。ここで仮りに交流を用いると異なった状況を呈するも のと思われるので, 今後は交流法についても検討を行い周波数を ある程度高めることによって, 相対き裂深さが 0.1 前後以下の表 面の損傷に対する検出能が高められることが期待される。また, $0.6 \mathrm{~A}$ 以上の直流の断続電流を流して試料の温度上昇をおさえな がら検出能を高める方法も検討している。

図 7 は, 図 5 に示したものと同様の電位差比曲線における試験 後期部分について拡大して示したものである。引張荷重が $80 \mathrm{kgf}$ のときも図 7 の 3 曲線と同様に電位差比曲線は破断直前に指数関 数的に増大している。図 6 と図 7 より破断直前の電位差比から破 断時のき裂深さ従って疲労破断部の面積割合が推定できる。

図 6 と図 7 の関係を総合すると, 破断前のき裂深さの進行状況 を示した図8が得られる。き裂は始めはゆるやかであるが後には かなり早く進行し, 引張荷重が $40 \mathrm{~kg}$ f ないし $60 \mathrm{kgf}$ ( 引張応力が $37 \mathrm{kgf}$ ないし $\left.56 \mathrm{kgf} / \mathrm{mm}^{2}\right)$ のときは相対き裂深さが $0.5 \sim 0.6$ に 達すると実験的に破断する。同様に引張荷重が $80 \mathrm{kgf}$ (引張応力 が $74 \mathrm{~kg} \mathrm{f} / \mathrm{mm}^{2}$ )のときは相対き裂深さが $0.4 \sim 0.43$ 位で破断する。

図 8 の曲線の勾配を求めると図 9 に示した平均の巨視的疲労き 裂伝ぱ速度の図が得られる。相対き裂深さが 0.1 付近のときの伝 ぱ速度はおよそ $10^{-4} \mathrm{~mm} / \mathrm{cycle}$ である。破断直前のそれは $10^{-3}$ $\mathrm{mm} / \mathrm{cycle}$ で 1 桁の違いがある。き裂が進展する途中の相対き裂 深さが 0.28 付近で, 伝ぱ速度が一様に増加せずに低下しているの が認められる。その原因として, 相対き裂深さが 0.28 付近を越え ると, 同一電位差比の増加分に対する相対き裂深さの増加分が小 


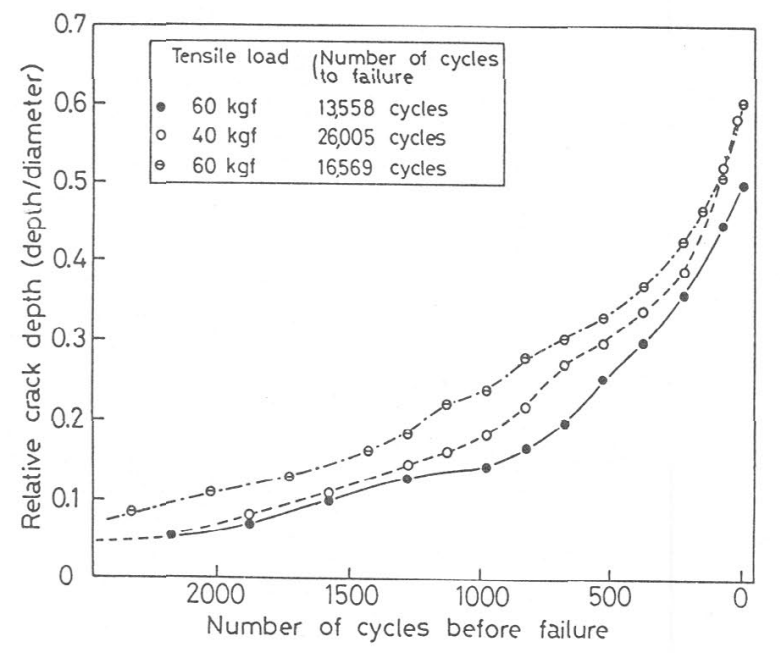

Fig. 8 Growth of crack depth.

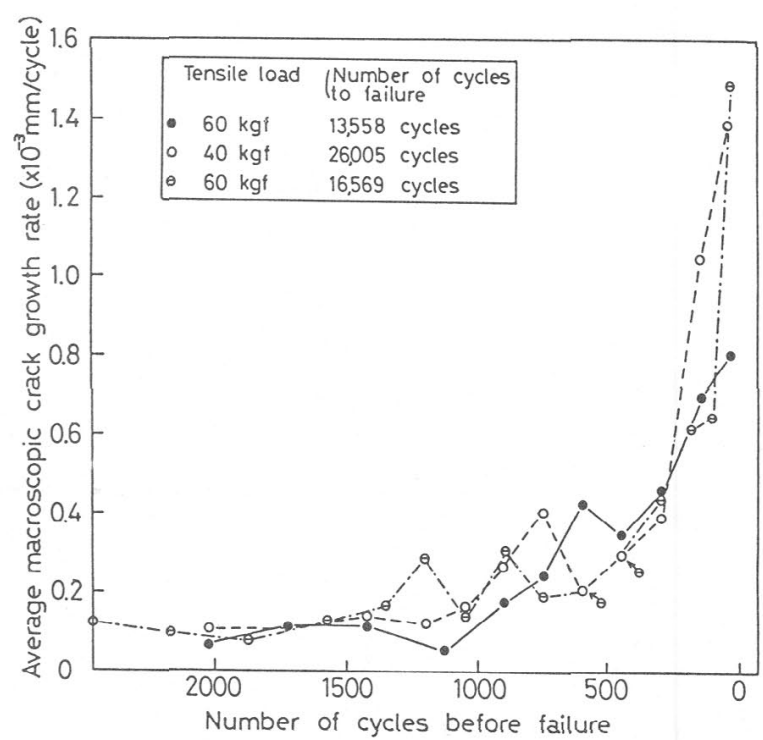

Fig. 9 Changing with time of average macroscopic crack growth rate before failure.

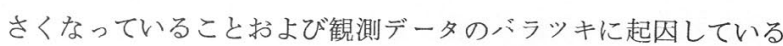
と考えられる。

図 5 においてAE信号が検出され始めた時期をき裂の発生時期 とみなすと, 本電位差法によってき裂を検出し始める時期(この ときの相対き裂深さは小さく見積って0.05 とする）に比べて時間 差はおよそ20分程度である。この間の平均の巨視的疲労き裂伝ぱ 速度は拉よそ $10^{-5} \mathrm{~mm} / \mathrm{cycle}$ となり, きわめて遅いき裂の進展で あることが分かる。

図10はき㤠発生点が2つで疲労破面が一様でない場合の一例を 示し, 図11 はき裂発生点が 1 つで疲労破面が一様な場合の典型的 な例を示し，本報における破断面はすべて後者の場合に該当して いる。図11上で右端のき裂発生点から破面の中心部に向って半径 の 5 分の 1 の位置 (相対深さ：0.1)における疲労破面を図12に示 与。図12の疲学破面に打けるさ裂の進行方向は右から左で, この 破面の不規則なミク口組織は試料の表面付近から中心部に向って ほとんど同じであるが，中心部付近では大きなき裂が認められる。 図12を詳細に観察すると右上部に縞模様が認められ，その間隔は 拉よそ $0.2 \mu \mathrm{m}$ すなわち $2 \times 10^{-4} \mathrm{~mm}$ で,電位差法で求めたき裂進展 速度とほぼ一致するので, この縞模様はストライエーションとみ られ疲学破面上のごく一部に散在しているものと考えられる。

実験結果より得られた巨視的疲労き裂伝ぱ速度は，鍋について 知られている通常の值 ${ }^{5)}$ とほぼ一致している。A E 法㧍よび電位 差法とも破断前にそれぞれ累積総数および電位差比の值が大きく なり，破断が近づいたことが分かり破断の予知を直前に行うこと が可能である。

\section{4. 結言}

本研究の実験と考察の結果, 得られた結論は次のとおりである。 1) き裂の発生時期は全寿命の㧍よそ 4 割位のときで, 電位差 法による検出開始時期に比べてかなり早い。き裂の発生時期の計 測には A E 法が，またき裂层ぱの比較的速い中期以降のき裂深さ の計測には電位差法が適している。き裂が急速に進展し始める比 較的初期の段階で相対き裂深さがおよそ 0.1 以下の場合には, 直 流法では計測が困難なので, 今後表面き裂に対する検出能が高い 交流法等を検討する必要がある。

2）電位差法によるき裂の検出開始時期は破断前の 2,000

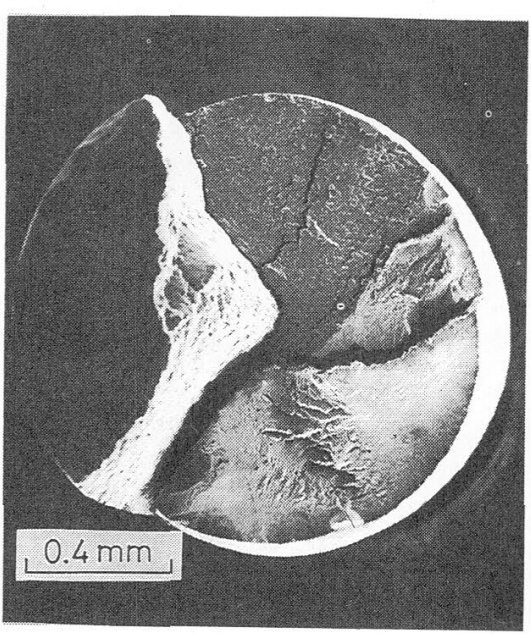

Fig. 10 Fracture face resulted from tension and pulsating bending. ( $\phi 1.25$, convexly upwards, tensile load: $80 \mathrm{kgf}$ )

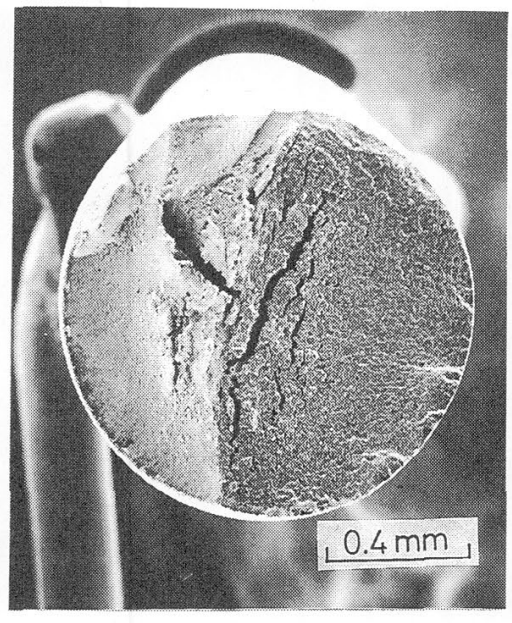

Fig. 11 Fracture face resulted from tension and pulsating bending. ( $\phi 1.17$, convexly upwards, tensile load: $60 \mathrm{kgf}$ )

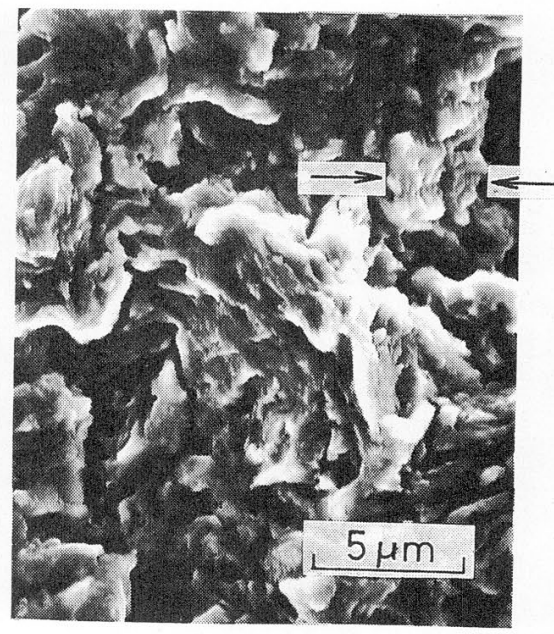

Fig. 12 Irregular fracture face in the fatigue fracture region. Relative crack depth is 0.1 . Arrows bracket striations. 
3,000 回で全寿命の残り $1 / 6 \sim 1 / 10$ に相当し, 破壊はその後短時 間のうちに急速に進展する。素線の疲労試験開始後, 疲労破壊が 急速に進展し始めるまでの時間は全寿命の $5 / 6 \sim 9 / 10$ 位なので, 素線を引張繰返し曲げを受ける部分に使用する場合, 破断する前 に取替えるまでの安全な使用時間が大きく（例えば全寿命の $1 / 2$ など）とれるので有効な使い方ができる。

3）相対切欠き深さが 0.1 程度以下の小さい場合は抵抗の変化 すなわち電位差比の変化もほとんど認められないが, それ以上で は切欠き深さとともに電位差比が徐々に増大し始めて, 切欠きに よる抵抗の変化分は切欠き部の断面積の減少量すなわち疲労破断 部の面積の $3 / 2$ 乗にほぼ比例して増大する。

本研究に用いた試料の素線を提供していただいた東京製鋼(株)
に謝意を表するとともに，セラミックボール軸受およびセラミッ クコーティング軸受の使用に便宜をはかっていただいた日本ピロ ーブロック製造(株)に謝意を表する。

\section{参考 文 献}

1）藤中雄三 ·上田和彦：日本釷業会誌，102[1181]，401 405, (1986)

2) 上田和彦: 昭和 62 年度資源・素材関係学協会合同秋季大会分科研 究会 (ワイヤロープ) 資料, 16〜19, (1987)

3). 仲佐博裕- 尾上守夫：材料科学, $13[1 \cdot 2], 29 \sim 45,(1976)$

4) 矢川元基・福田俊彦：機械の研究, $35[11], 29 \sim 31,(1983)$

5）たとえば北川英夫，小寺沢良一：フラクトグラフィ，103１08， (1977），培風館（東京）

\section{新刊紹介}

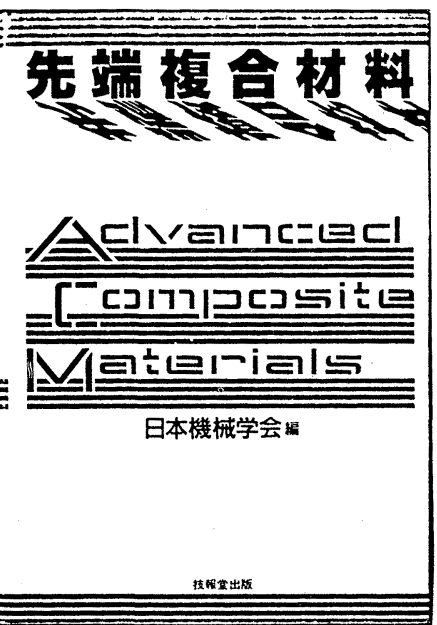

\section{日本機械学会編}

\section{“先端複合材 料”}

\section{技報堂出版 $1990<\mathrm{A} 5 \cdot 279$ 頁・4,635円 $>$}

本書は, 斯界の第一線の方々に執筆を願 い,できるだけ平易に A C M ( 先端複合材 料 ) の最新技術についてその概要を網羅し, 機械関係の研究者, 技術者, 経営者方にそ の全体像を把握し，応用開発に資するよう な配慮のもとに編纂した。(序より拔粋 )

$$
\text { 目次 }
$$

第 1 章 複合材料の沿革と先端材料

第 2 章 高性能纎維とマトリックス

第 3 章 エンジニアリングプラスチック

第 4 章 プラスチック基先端複合材料の 物性

第 5 章 プラスチック基先端複合材料の 力学

第 6 章 プラスチック基先端複合材料の 設計の最適化

第 7 章 プラスチック基先端複合材料の 成形法
第 8 章 熱可塑性樹脂系複合材料の特性 と成形加工法

第 9 章 金属基複合材料の成形法と特性

第10章 繊維強化セラミックスの特性と 応用

第11章 C / C コンポジットの特性と応 用

第12章 エラストマー系複合材料の特性 と応用

第13章 3 次元織物の開発と応用

第14章 機能性複合材料の特性と応用

第15章 複合材料の破壊力学的評価法

第16章 先端複合材料の非破壊検査法

第 17 章 先端複合材料の二次加工

第18章 先端複合材料の応用と可能性

技報堂出版(株)：03(585) 0166 